Aldona Zakrzewska*

Olsztyn

\title{
Współczesna szkoła katolicka placówką kształtowania społecznie dojrzałej osobowości dzieci i młodzieży
}

Podstawą współczesnej szkoły katolickiej jest integralne wychowanie, które stanowi klucz do wychowania jednostek społecznie dojrzałych, czyli świadomie angażujących się nie tylko na rzecz swojego dobra, ale również na rzecz dobra wspólnego społeczności, w których żyją. Takie jest założenie tej placówki oświatowej. Jak natomiast wygląda jej rzeczywistość edukacyjna? W jakim stopniu i jakimi środkami realizuje się zapisy zawarte w jej programach wychowawczych? Czy faktycznie stanowi ona ważne ogniwo wychowania obywatelskiego podejmowanego przez instytucjonalne środowiska wychowawcze? Niniejsze pytania stanowiły inspirację podjętych rozważań. Zanim jednak do nich przystąpię, wyjaśnię na wstępie rozumienie i granice stosowanych $\mathrm{w}$ artykule terminów.

Kształtowanie społecznie dojrzałej osobowości traktuję w kategoriach szerokiego spektrum pojęcia socjalizacji, określanej też mianem procesu uspołecznienia, a więc nabywania przez jednostkę społecznej dojrzałości,

* Dr Aldona Zakrzewska jest adiunktem w Katedrze Dydaktyki i Historii Wychowania Wydziału Nauk Społecznych Uniwersytetu Warmińsko-Mazurskiego w Olsztynie. Adres: Katedra Dydaktyki i Historii Wychowania, Wydział Nauk Społecznych Uniwersytetu Warmińsko-Mazurskiego w Olsztynie, ul. Prawocheńskiego 13, 10-725 Olsztyn; e-mail: aldona61@ wp.pl. 
czyli kompetencji społecznych ${ }^{1}$. Tak pojmowane działanie wchodzi w zakres wychowania obywatelskiego propagującego ideę społeczeństwa obywatelskiego, realizującego między innymi funkcję socjalizacyjną ${ }^{2}$. Zasadza się ono na formowaniu obywatelskich wzorców funkcjonowania, czyli kształtowaniu demokracji, co ma zabezpieczać społeczeństwo przed autokratycznym zachowaniem władz państwowych oraz dyktatorskim działaniem grup społecznych. Istotą kształtowania obywatelskiego postępowania jest wychowanie do odpowiedzialności, akceptacji, uczciwości, zaufania społecznego oraz odwagi obywatelskiej i niezgody na działania godzące w demokrację ${ }^{3}$. Z kolei współczesną szkołę katolicką odnoszę do polskich placówek oświatowo-wychowawczych, które odrodziły się po 1989 roku$^{4}$ i stanowią w rzeczywistości edukacyjnej jedno z coraz bardziej zauważalnych środowisk wychowawczych ${ }^{5}$, postrzeganych przez niektórych jako instytucja odgrywająca istotną socjalizacyjnie rolę w życiu przyszłych pokoleń ${ }^{6}$.

1 Jerzy Modrzewski, Dorota Sipińska, „Socjalizacja”, w: Encyklopedia pedagogiczna XXI wieku, t. 5, red. Tadeusz Pilch (Warszawa: Wydawnictwo Żak, 2006), 804.

${ }^{2}$ Krystyna Kietlińska, Rola trzeciego sektora w społeczeństwie obywatelskim (Warszawa: Wydawnictwo Dyfin, 2010), 17.

${ }^{3}$ Piotr Broda-Wysocki, Rozwój społeczeństwa obywatelskiego w Polsce (Warszawa: IPiSS, 2003), 38.

${ }^{4}$ Adam Maj, Szkolnictwo katolickie w III RP (1989-2001) (Warszawa: Wydawnictwo Adam, 2002), 193-195.

${ }^{5}$ Przed okresem transformacji ustrojowej funkcjonowało jedynie 14 szkół katolickich prowadzonych przez zgromadzenia zakonne. Dziesięć lat później (1999 r.) było ich 276, w roku szkolnym 2009/2010 istniało 518 szkół z ponad 55 tys. uczniów, a w 2013/2014 działało 582 placówek, w których naukę pobierało ok. 60 tys. dzieci i młodzieży. Aktualnie zakładają je i prowadzą diecezje, parafie, zakony, stowarzyszenia i osoby fizyczne. Zob. Maj, Szkolnictwo, 172-192; Rada Szkół Katolickich, Informator adresowy szkół katolickich w Polsce (Warszawa: Rada Szkół Katolickich, 2011), 85; Rada Szkół Katolickich, Informator adresowy szkół katolickich w Polsce (Warszawa: Rada Szkół Katolickich, 2014), 102; http://wnk.kuria. zg.pl/szkoly_katolickie_w_polsce.html (27.09.2015); http://www.rsk.edu.pl/index.php?option $=$ com_content $\&$ view $=$ article $\&$ id $=93$ :szkoa-z-dusz\&catid $=48:$ media-o-rsk\&Itemid $=161$ (27.09.2015).

${ }^{6}$ Por. m.in.: Jan Paweł II, „Wychowanie katolickie uwrażliwia na potrzeby innych”. Spotkanie z młodzieżą High School w Madison Square Garden w Nowym Jorku, Nowy Jork (USA), 3.10.1979, w: Szkoła katolicka w nauczaniu Kościoła. Wybór dokumentów, red. Andrzej Dymer (Szczecin-Warszawa: Centrum Edukacyjne Archidiecezji Szczecińsko-Kamieńskiej, 2002), 101-102; Stanisław Sławiński, „Uczeń szkoły katolickiej. Wychowanie do odpowiedzialności”, Ateneum Kapłańskie 3 (2007), 477-485; Zenon Grocholewski, „Potrzebna jest szkoła katolicka. Słowo kard. Zenona Grocholewskiego podczas uroczystej sesji związanej z nadaniem Mu tytułu Przyjaciel Szkół Katolickich w Polsce”, w: Rada Szkół Katolickich, 


\section{Tożsamość szkoły katolickiej - wyjściem naprzeciw realizacji idei społecznie dojrzałej osobowości}

Szkoły katolickie stanowią „cząstkę ewangelicznej misji kościoła”, ponieważ zrodziły się w rzeczywistości edukacyjnej, również polskiej, na kanwie Chrystusowego zalecenia, wzywającego uczniów do podjęcia misji wychowawczej: „Idąc, nauczajcie wszystkie narody” (Mt 28, 18-19) ${ }^{8}$. Posłannictwo szkoły katolickiej kształtowania społecznie dojrzałej osobowości wynika z jej tożsamości zasadzonej na syntezie „między kulturą i wiarą oraz wiarą i życiem" " Na jej szczególny charakter składają się między innymi: chrystocentryzm, integralność w wychowaniu i kształceniu powiązane ściśle z personalistyczną ideą edukacji oraz systematyczne i krytyczne przekazywanie kultury zgodnie z chrześcijańską wizją rzeczywistości. Poniżej charakteryzuję pokrótce te cechy.

Specyfika placówki katolickiej wynika z uwewnętrznienia przez jej wspólnotę pedagogii Chrystusa, co sprawia, że program wychowawczy placówki inspirowany jest zasadami ewangelicznymi ${ }^{10}$. Wspominał o tym niejednokrotnie Jan Paweł II, który zauważał: „Szkoła katolicka winna [nie tylko - A. Z.] odróżniać się od szkoły państwowej poziomem organizacyj-

Spotkanie nauczycieli szkót katolickich w Polsce z kard. Zenonem Grocholewskim-Prefektem Kongregacji Edukacji Katolickiej (Warszawa: Rada Szkół Katolickich, 2008), 24-25; Aldona Zakrzewska, „Pedagogia szkoły katolickiej alternatywą wychowania w dobie ponowoczesności”, w: Opieka i wychowanie - tradycja i problemy współczesne, red. Danuta Apanel (Kraków: Wydawnictwo Impuls, 2009), 147-157; Aldona Zakrzewska, ,Szkoła katolicka - jej (bez)sens istnienia w środowisku lokalnym", w: Różne oblicza funkcjonowania szkoły, red. Lucyna Hurło, Małgorzata Przybysz-Zaremba (Olsztyn: Wydawnictwo Prospekt, 2010), 189-199.

7 Jan Paweł II, „Szkoła katolicka czerpie swą inspirację od Jezusa Chrystusa”, spotkanie z przedstawicielami Braci Szkół Chrześcijańskich, Rzym, 21.XI.1981, w: Wychowanie w nauczaniu Jana Pawła II, red. Adam Wieczorek (Warszawa: Wyższa Szkoła Zarządzania i Przedsiębiorczości im. Bogdana Jańskiego, 2000), 168.

${ }^{8}$ Michał Klepacz, Duchowieństwo wobec nowoczesnych prąów w szkole polskiej (Kielce: Drukarnia św. Józefa, 1930), 73.

${ }^{9}$ Kongregacja ds. Wychowania Katolickiego, „Szkoła katolicka”, w: Stużyć wzrastaniu w prawdzie i miłości. Wybór dokumentów Kościoła na temat szkoły katolickiej $i$ wychowania, red. Janusz Poniewierski (Kraków: Wydawnictwo AA, 2009), 36-48. Por. Adam Maj, „Wartości religijne konstytuujące tożsamość szkoły katolickiej”, w: Kreowanie tożsamości szkoły, t. 2: Konteksty historyczne, społeczno-kulturowe, edukacyjne, red. Krystyna Chałas, Beata Komorowska (Lublin: KUL, 2009), 561-571.

${ }^{10}$ Kongregacja ds. Wychowania Katolickiego, „Szkoła katolicka”, 34. 
nym i metodologicznym, czyli większą powagą dydaktyczną, lecz także specyficznym ukształtowaniem całości, które, zarówno materiał nauczania, jak i osobę ucznia, stawia w szerszych ramach planu Bożego w odniesieniu do człowieka, zrealizowanego i przedstawionego w Jezusie Chrystusie"11.

Wychowanie w szkole katolickiej powinno objąć pełną formację osoby ludzkiej, a więc musi być holistyczne ${ }^{12}$. Wynika to z faktu, że „w Chrystusie, Człowieku doskonałym, wszystkie ludzkie wartości znajdują pełne urzeczywistnienie i harmonijną jedność. [...] On jest wzorem i przykładem życia, które szkoła katolicka proponuje młodym"13. Jan Paweł II, kierując się ową perspektywą, zwracał uwagę, iż:

trzeba stworzyć szkołę katolicka, która by w łonie wspólnoty lokalnej umiała być rzeczywistym miejscem integralnej formacji osoby przy pomocy wypracowania i przyswojenia kultury ludzkiej w jej różnych formach i wyrazach; miejscem kształtowania do wolności i do odpowiedzialności, do smaku piękna i do twórczości artystycznej, do otwarcia wobec innych i wobec społeczności [...] u podstaw wizji życia winna umieścić Jezusa Chrystusa i Jego orędzie zbawienia. W ten sposób, bez wypierania się swojej natury szkoły przeznaczonej dla przekazywania wszelkiej wiedzy, osiaga ten cel w chrześcijańskiej wizji rzeczywistości, za pomocą której kultura otrzymuje swoje uprzywilejowane miejsce $w$ integralnym powołaniu człowieka. Będzie szkoła, która potrafi doprowadzić do dojrzałości uzdolnienia tkwiące w każdym młodym człowieku i w świetle różnych sytuacji rodzinnych, moralnych i społecznych, umie przygotować go do podejmowania dobrych decyzji. Szkoła, która podaje przejrzyście i bez sztuczności wartości znajdujące wyraz w ewangelii i w stałej nauce Kościoła ${ }^{14}$.

11 Jan Paweł II, „Świadomość specyfiki szkoły katolickiej”, audiencja dla nauczycieli i uczniów instytutów szkolnych prowadzonych przez zakonnice, Watykan, 27.XI.1982, w: Wychowanie w nauczaniu Jana Pawła II, red. Adam Wieczorek (Warszawa: Wyższa Szkoła Zarządzania i Przedsiębiorczości im. Bogdana Jańskiego, 2000), 218-219.

12 Marek Sygut, „Szkoła katolicka - kontekst prawny”, Ignacjański Model Wychowania 1 (1995): 52.

13 Kongregacja ds. Wychowania Katolickiego, „Szkoła katolicka”, 35.

14 Jan Paweł II, „Szkoła katolicka miejscem integralnej formacji młodego człowieka”, audiencja dla uczestników zebrania generalnego Federacji Instytutów Działalności Wychowawczej (FIDAE), Rzym, 28.12.1981, w: Wychowanie w nauczaniu Jana Pawła II, red. Adam Wieczorek (Warszawa: Wyższa Szkoła Zarządzania i Przedsiębiorczości im. Bogdana Jańskiego, 2000), 180. 
Integralny rys wychowania $\mathrm{w}$ szkole katolickiej wynika z przyjętej przez nią personalistycznej wizji człowieka ${ }^{15}$. W związku z tym jej celem jest promocja osoby ludzkiej w jej całościowym ujęciu, ze wszystkimi ludzkimi wartościami ,znajdującymi pełne urzeczywistnienie i w konsekwencji swą jedność w Chrystusie"16. Przyjęty personalizm chrześcijański nakazuje też, aby szkoła katolicka traktowała każdą osobę, zarówno pracowników, jak i rodziców czy ich dzieci, jako, ,podmiot myślący i zdolny do samostanowienia" ${ }^{17}$, a wychowanie jako ,szukanie celów prawdziwych, czyli prawdziwych dóbr jako celów działania, oraz [...] znajdowanie i pokazywanie dróg do ich realizacji”'18. Wobec tego w szkole katolickiej „kształtowanie osoby w kierunku dobra nie może dokonywać się inaczej, jak przez współdziałanie, uczestnictwo, przez wykonywanie wolności. Wychowanie jest więc przede wszystkim dziełem osoby, która jest kształtowana [wychowanka A. Z.], jej aktywizowaniem, pobudzaniem do współtworzenia, stwarzaniem warunków, w których może rozwijać się wolność osoby"19. Szkoła katolicka przyjmuje zatem podmiotowy charakter procesu wychowania, w którym dwa podstawowe jego elementy - wychowanek i wychowawca - stanowią dwa podmioty niepodzielnie ważne i wolne.

W szkole katolickiej każdy wymiar wychowania podlega wychowaniu chrześcijańskiemu ${ }^{20}$. W związku z tym:

całe życie ludzkie: fizyczne, duchowe, intelektualne, moralne, indywidualne, rodzinne i społeczne, podlega wychowaniu chrześcijańskiemu. [...] Stąd prawdziwy chrześcijanin, wychowany według wzoru ewangelicznego, jest człowiekiem nadprzyrodzonym, to jest takim, który myśli, sądzi i działa stale i konsekwentnie wedle wskazówek zdrowego rozumu, oświeconego nadprzyrodzonym światłem przykładów i nauki Chrystusa. [...] Nie ten posiada solidny charakter,

${ }^{15}$ Maj, „Wartości”, 568.

${ }^{16}$ Kongregacja do Spraw Wychowania, „Szkoła katolicka u progu trzeciego tysiąclecia”, w: Stużyć wzrastaniu w prawdzie i miłości. Wybór dokumentów Kościoła na temat szkoły katolickiej $i$ wychowania, red. Janusz Poniewierski (Kraków: Wydawnictwo AA, 2009), 9.

${ }^{17}$ Karol Wojtyła, Miłość i odpowiedzialność (Lublin: KUL 2001), 29.

18 Tamże.

19 Stanisław Chrobak, Koncepcja wychowania personalistycznego w nauczaniu Karola Wojtyly - Jana Pawła II (Warszawa: Wydawnictwo Salezjańskie, 1999), 55.

${ }^{20}$ Kongregacja ds. Wychowania Katolickiego, ,,Szkoła katolicka”, 36. 
kto postępuje według niestałych i subiektywnych zasad, lecz ten, kto wytrwale kieruje się odwiecznymi zasadami sprawiedliwości ${ }^{21}$.

Wszystkie te charakterystyczne rysy szkoły katolickiej sprawiają, że ma ona na uwadze wychowanie nie takich chrześcijan, którzy się tylko modlą i czekają na cudowne działanie Opatrzności Bożej, ale chrześcijan, „którzy będą [...] wzorowymi obywatelami, zdolnymi do pełnego wkładu swojej inteligencji, solidności, kompetencji w dzieło prawidłowego i porządnego budowania społeczeństwa obywatelskiego"22. Dzieje się tak, ponieważ szkoła katolicka ma z założenia wychowywać ku wartościom, przede wszystkim wychowywać do prawdy przez wielkie i małe „p”, do obowiązku konsekwencji i świadectwa, do miłości, ujmowanej również w aspekcie ludzkiej wrażliwości ${ }^{23}$, „czyli w szacunku dla bliźniego, w poczuciu demokratycznej tolerancji, unikając sztywności i narzucania, polemik i wrogości. Młody chrześcijanin winien być wychowany do życia i do współżycia, wnosząc miłość Chrystusa, a więc miłość bliźniego, solidarność, nadzieję, ufność, współczucie"24.

\section{Szkoła katolicka instytucją wychowania ku wartościom społecznym}

Kształtowanie społecznie dojrzałej osobowości odbywa się w dużej mierze na drodze wychowania ku wartościom, w tym także wartościom społecznym - heterotelicznym, czyli normom funkcjonowania jednostek nadrzędnych, na przykład rodziny, narodu, państwa, co prowadzi do przyjęcia ich celów za własne. Te z kolei nie są w stanie zaistnieć w życiu człowieka

${ }^{21}$ Pius XI, „Encyklika Divini Ilius Magistri O chrześcijańskim wychowaniu młodzieży”, w: Stużyć wzrastaniu w prawdzie i miłości. Wybór dokumentów Kościoła na temat szkoły katolickiej $i$ wychowania, red. Janusz Poniewierski (Kraków: Wydawnictwo AA, 2009), 70.

22 Jan Paweł II, „Przemówienie do nauczycieli i wychowanków rzymskich kolegiów: Massimo i Santa Maria”, w: Stużyć wzrastaniu w prawdzie i miłości. Wybór dokumentów Kościoła na temat szkoły katolickiej i wychowania, red. Janusz Poniewierski (Kraków: Wydawnictwo AA, 2009), 195.

23 Jan Paweł II, „Przemówienie do uczestników Zgromadzenia Generalnego Federacji Instytutów Działalności Wychowawczej (FIDAE)", Rzym, 28.12.1985, w: Stużý wzrastaniu w prawdzie i miłości. Wybór dokumentów Kościoła na temat szkoły katolickiej $i$ wychowania, red. Janusz Poniewierski (Kraków: Wydawnictwo AA, 2009), 3.

${ }^{24}$ Tamże. 
bez wartości fundamentalnych, czyli wartości autotelicznych i ideotelicznych $^{25}$. Autotelia odnosi się do realizacji celów własnych osoby wobec osób jej równorzędnych, co w relacjach interpersonalnych przejawiać się może sympatią, przyjaźnią czy miłością. Natomiast ideotelia polega na interioryzacji najwyższych idei ludzkości, a mianowicie Prawdy, Dobra, Piękna i Świętości ${ }^{26}$.

Wartości odgrywają w życiu człowieka i społeczeństw ważną rolę. Edukacja ukierunkowana na wartości rozwija i kształtuje nie tylko nas samych, ale również decyduje o naszym bycie, o istocie i jakości życia, o relacjach międzyludzkich, o kompetencjach podejmowania trudnych wyborów, o odnoszeniu się do samego siebie i do innych oraz o stosunku do grup społecznych, w których egzystujemy ${ }^{27}$. Katarzyna Olbrycht zaznacza, iż brak wartości w życiu ludzkim jest niebezpieczne charakterologicznie i egzystencjalnie, ponieważ prowadzi do bezkrytycznego przyjmowania wszystkiego, a w konsekwencji do braku tożsamości i zachwiania osobowego ${ }^{28}$. Według Stanisława Michałowskiego, wychowanie do wartości pełni specyficzne posłannictwo nie tylko w odniesieniu do rozwoju osobowego, ale także społecznego, gdyż rozwój ten zachodzi „...tylko przez dążenie człowieka do różnorodnych wartości, które pociagają ku sobie, zmuszają do dokonywania wyborów i podejmowania różnorodnych decyzji" 29 .

Jan Paweł II, zwracając się do uczestników jednego z kongresów szkół katolickich, podkreślał, iż ,we współczesnym społeczeństwie wychowanie do wartości jest $[\ldots]$ najpoważniejszym wyzwaniem dla $[\ldots]$ społeczności edukacyjnej" ${ }^{30}$. Z czego to wynika? W nowoczesnym społeczeństwie nastąpił szereg przemian wartości i norm moralnych. Przyczyn tego stanu rzeczy

${ }^{25}$ Kryterium przyjętej klasyfikacji wartości stanowią drogi rozwoju osobowości w ujęciu Williama Sterna, niemieckiego psychologa i pedagoga, reprezentanta personalizmu krytycznego.

${ }^{26}$ Stefan Kunowski, Podstawy współczesnej pedagogiki (Warszawa: Wydawnictwo Salezjańskie, 1996), 120-121.

${ }^{27}$ Kazimierz Denek, „Wartości i cele edukacji szkolnej”, Edukacja 3 (2000): 4, 7.

${ }^{28}$ Katarzyna Olbrycht, Prawda, dobro i piękno w wychowaniu człowieka jako osoby (Katowice: UŚ, 2000), 104.

29 Stanisław Michałowski, Pedagogia wartości (Bielsko-Biała: Wydawnictwo Debit, 1993), 52.

30 Jan Paweł II, „Wychowanie do wartości moralnych. Audiencja dla uczestników XIV Światowego Kongresu Szkół Katolickich”, 5.03.1994, w: Wychowanie w nauczaniu Jana Pawła II (1978-1999), red. Stanisław Urbański (Warszawa: Wyższa Szkoła Zarządzania i Przedsiębiorczości im. Bogdana Jańskiego, 2000), 361-362. 
upatruje się między innymi w sekularyzacji wartości, indywidualizacji religijności, powstawaniu nowej obyczajowości (zastępowanie jednych wartości innymi, np. niechęć do wysiłku w życiu publicznym, a wielka praca dla siebie - nauka), fundamentalizmie (przesuwaniu się sfery profanum na teren sacrum czy tworzeniu się pseudoreligii wskutek przekształceń zachodzących w ramach sacrum) ${ }^{31}$.

Pociaga to za sobą troskę inwestowania w wychowanie młodych i zwracanie uwagi na środowisko wychowawcze jako istotny czynnik w kształtowaniu (formacji) dzieci i młodzieży. Pojawia się tu pole do działania szkół katolickich, które w oparciu o program wychowawczy, odwołujący się do nauki społecznej Kościoła, mogą wytworzyć pozytywne środowisko wychowawcze, zapewnić wychowanie w duchu miłości i do miłości, kształtując w wychowanku właściwy system wartości. Prawidłowe środowisko wychowawcze szkoły jest potrzebne dziecku nie tylko dlatego, że obecnie polska rodzina jest słaba i należy pomóc jej w wychowaniu młodego pokolenia. Wynika to również z nowych niebezpieczeństw pojawiających się w związku z przemianami w życiu społecznym, szczególnie miejskim (zurbanizowanym), w którym: czas staje się jedną z centralnych wartości, jednym z najbardziej poszukiwanych dóbr (usługi mają być świadczone błyskawicznie, natychmiastowo, co prowadzi do ich powierzchowności); ciagłe konfrontowanie się z bombardującymi nas nowymi znakami nie pozwala poczuć się w mieście jak u siebie (dominuje poczucie zagubienia, niemożności, osamotnienia wobec wielu wyzwań miejskich, osierocenia); medialna kreacja świata, z jego konsumpcjonizmem, kultem cielesności, brutalnością, marzeniami na poziomie uczestnictwa $\mathrm{w}$ reality show $\mathrm{i}$ wszechobecna $\mathrm{w}$ szkolnictwie liberalna koncepcja wychowania nie wprowadza żadnych granic wolności, która staje się samowolą, co w konsekwencji uniemożliwia dialog społeczny rozumiany jako spotkanie w przestrzeni wartości ${ }^{32}$.

Dokonana przez ks. Adama Maja analiza wyników badań empirycznych przeprowadzonych w polskich szkołach katolickich w 2001 roku wskazuje, że to wyzwanie jest przez nie realizowane. Podstawę poddanych analizie programów wychowawczych stanowi spektrum wartości obejmujących chrześcijański system wartości zawarty w Dekalogu i Ewangelii, wartości społeczne i patriotyczne, a więc mieszczą one nie tylko wartości autoteliczne, ale także ideoteliczne i heteroteliczne. Wśród wartości zaczerpniętych z De-

31 Janusz Mariański, Kryzys moralny czy transformacja wartości? (Lublin: KUL, 2001), 69.

32 Teresa Śliwińska, „Potrzeba zakładania szkół katolickich”, Katecheta 3 (2003): 69-72. 
kalogu i Ewangelii odnajdujemy najczęściej: Boga, wiarę, miłość do Boga i ludzi, Prawdę, mądrość, dobro, piękno, przebaczenie, wierność, dobroć, wrażliwość, wspólnotę, godność, szacunek, odpowiedzialność, uczciwość, służbę, pracę nad sobą. Dodatkowo - w zestawie wartości społeczno-patriotycznych - przywoływane były często: więź z krajem, świadomość obywatelska, odpowiedzialność za dobro wspólne, poszanowanie dla historii, tradycji i kultury narodowej, lokalnej i rodzinnej, przy zachowaniu szacunku wobec innych kultur, tolerancja i zrozumienie, pokój i bezpieczeństwo, sprawiedliwość społeczna, szacunek dla pracy ${ }^{33}$.

Wydaje się, iż wychowanie do wartości, stanowiące fundament społecznie dojrzałej osobowości, obecne w polskich szkołach katolickich, realizowane jest efektywnie, ponieważ placówki te opierają się w swoim funkcjonowaniu na wspomnianym wcześniej personalizmie chrześcijańskim, który zakłada podmiotowy styl wychowania. Ta korelacja jest nieodzowna, gdyż „wychowanie do wartości jest wychowaniem osobowym traktowanym jako spotkanie osób [...]: mistrza-wychowawcy z innym człowiekiem wychowankiem-uczniem"34.

Faktem wydaje się także naturalne otwarcie szkół katolickich na życie społeczne poprzez kształtowanie w uczniach społecznie dojrzałej osobowości, ponieważ obecne w nich:

wychowanie chrześcijańskie wymaga - jak zaznacza Kongregacja do Spraw Wychowania Katolickiego - szacunku dla państwa i jego przedstawicieli, przestrzegania słusznych praw, dążenia do wspólnego dobra. Tak więc wszelkie ważne sprawy, takie jak: wolność, sprawiedliwość, praca, postęp, mają swoje miejsce w planie wychowawczym i są rozważane w środowisku szkolnym. [...] W ten sam sposób traktuje się problemy wspólnoty międzynarodowej. W wychowaniu chrześcijańskim ludzkość traktowana jest jako jedna wielka rodzina, chociaż podzielona z powodów historycznych i politycznych, to jednak zawsze zjednoczona w Bogu, Ojcu wszystkich ludzi. Tak też wezwania Kościoła do pokoju, sprawiedliwości, wolności i dobra dla wszystkich narodów, braterskiego wspomagania uboższych, powinny zostać odpowiednio przyjęte w szkole ${ }^{35}$.

33 Maj, Szkolnictwo, 230-233.

${ }^{34}$ Waldemar Furmanek, „Wychowanie do wartości drogą budowania tożsamości szkoły”, w: Kreowanie tożsamości szkoły, t. 2: Konteksty historyczne, społeczno-kulturowe, edukacyjne, red. Krystyna Chałas, Beata Komorowska (Lublin: KUL, 2009), 188.

${ }^{35}$ Kongregacja ds. Wychowania Katolickiego, „Religijny wymiar wychowania w szkole katolickiej”, w: Stużyć wzrastaniu w prawdzie i miłości. Wybór dokumentów Kościoła na te- 
Z drugiej jednak strony - jak zauważa wspomniana wyżej Kongregacja do Spraw Wychowania Katolickiego - do wielu szkół katolickich wkradła się na przestrzeni dziejów, co dzieje się również współcześnie, słabość ich funkcjonowania polegająca na tym, iż pięknie zapisany program wychowawczy pozostaje jedynie w płaszczyźnie deklaratywnej, przez co nie służą one we właściwy sposób Kościołowi i społeczeństwu ${ }^{36}$. Mając to na uwadze, szkoły katolickie, w trosce o wierność swym programom wychowawczym, powinny nieustannie oddawać się samokrytyce i powracać do źródeł ${ }^{37}$.

Podjęty aspekt jest jednak niezwykle złożony. Sama „czujność” szkół katolickich w zakresie realizacji zamierzonych celów wychowawczych nie wystarczy. Przemiany społeczne niosą ze sobą coraz to liczniejsze problemy natury wychowawczej, ponieważ:

szkoła katolicka spotyka się z młodzieżą i dziećmi przeżywającymi trudności obecnego czasu. Musi dać sobie radę z uczniami, którzy unikają wysiłku, są niezdolni do poświęcenia i stałości i - zaczynając od rodziny - nie mają pozytywnych wzorców, na których mogliby się oprzeć. Coraz liczniejsze są wśród nich przypadki indyferentyzmu, zaniedbywania praktyk religijnych; niektórzy pozbawieni są nawet jakiejkolwiek formacji religijnej czy moralnej. Co więcej, wielu uczniów, jak i wiele rodzin przejawia głęboką niewrażliwość na formację etyczną i religijną, toteż w rezultacie oczekuje się od szkoły katolickiej jedynie możliwości uzyskania dyplomu lub co najwyżej wykwalifikowanej opieki dydaktycznej i przygotowania do zawodu ${ }^{38}$.

\section{Zakończenie}

Przedstawione $\mathrm{w}$ artykule refleksje na temat kształtowania społecznie dojrzałej osobowości w oparciu o wychowanie do wartości wydają się niezwykle ważne, ponieważ współczesna europejska rzeczywistość społeczna i gospodarcza oparta na globalizacji, pluralizmie i wolnorynkowej gospodarce pociąga za sobą poważne problemy, chociażby wzrastające zjawisko wie-

mat szkoty katolickiej i wychowania, red. Janusz Poniewierski (Kraków: Wydawnictwo AA, 2009), 45.

${ }^{36}$ Kongregacja ds. Wychowania Katolickiego, „Szkoła katolicka”, 65.

37 Tamże, 67.

38 Kongregacja ds. Wychowania Katolickiego, „Szkoła katolicka u progu trzeciego tysiąclecia", 6 . 
lokulturowości czy bezrobocie, ubóstwo, przestępstwa i korupcja, co w konsekwencji powoduje społeczne zagubienie aksjologiczne. Obecny w Europie kryzys wartości przybiera formy wszechobecnego subiektywizmu, relatywizmu moralnego i nihilizmu ${ }^{39}$. Wobec tego wychowanie do wartości podejmowane przez szkoły katolickie może stanowić pewnego rodzaju antidotum wobec współczesnego świata prowadzącego coraz częściej do społecznej niechęci, nietolerancji, katastrofizmu, instynktowości czy chciwości i prywaty, ponieważ, jak zaznaczał w swym nauczaniu Jan Paweł II „wartości są [...] podstawą, która nie tylko decyduje o [...] życiu, ale także określa linie postępowania i strategie, które budują życie w społeczeństwie" ${ }^{40}$. Natomiast w przesłaniu, skierowanym do XI Kongresu Międzynarodowego Biura Wychowania Katolickiego, ukazał szkołę katolicką jako wyjątkowe dobrodziejstwo dla współczesnych zagrożeń społecznej rzeczywistości. Wskazywał on, iż:

Szkoła katolicka, ciesząca się dobrodziejstwem światła wiary, znajduje się w pozycji uprzywilejowanej, by umożliwić swoim uczniom wykształcenie w duchu istotnych wartości dla zachowania świata wolnego od gróźb, jakie dziś nad nim wiszą. W ten sposób młodzież nauczy się odrzucać fałszywe wartości chylącego się ku upadkowi społeczeństwa i odkrywać wartości prawdziwe, na których może być zbudowana cywilizacja miłości ${ }^{41}$.

Czy tak jest rzeczywiście? Pojawiają się na tej płaszczyźnie liczne wątpliwości ${ }^{42}$. Obiekcje budzi chociażby funkcjonujący w niektórych szkołach

39 Tamże, 1; por. Lucyna Hurło, „Hierarchia wartości wśród młodzieży. Prawda czy złudzenie”, w: Pedagogika chrześcijańska. Tradycja, współczesność, nowe wyzwania, red. Jarosław Michalski, Aldona Zakrzewska (Toruń: Wydawnictwo Adam Marszałek, 2010), 438-447.

40 Jan Paweł II, Orędzie na XVIII Światowy Dzień Pokoju „Pokój i młodzi idq razem”, Watykan, 8.12.1984, 6.

41 Jan Paweł II, „Przesłanie do XI Kongresu Międzynarodowego Biura Wychowania Katolickiego", w: Stużyć wzrastaniu w prawdzie i miłości. Wybór dokumentów Kościoła na temat szkoły katolickiej i wychowania, red. Janusz Poniewierski (Kraków: Wydawnictwo AA, 2009), 156.

42 Wattpliwości w przywołanych kwestiach wyrażali rodzice, nauczyciele, dyrektorzy i przedstawiciele organów prowadzących szkoły katolickie, a także naukowcy zgromadzeni m.in. na następujących spotkaniach i konferencjach, w których uczestniczyła także autorka artykułu: coroczne Forum Szkół Katolickich w Częstochowie organizowane przez Radę Szkół Katolickich; Ogólnopolskie Posiedzenie Zespołu Pedagogiki Chrześcijańskiej w Lublinie pt. Szkoła katolicka we wspótczesnym świecie (3.06.2015); IV Międzynarodowy Kongres Religioznawczy w Gdyni (17-20.06.2015), sekcja Pedagogiki Religii. 
katolickich system rekrutacji, który nie jest do końca klarowny i transparentny. W wielu przypadkach są to placówki niepubliczne, pobierające czesne, a więc szkoły elitarne, niedostępne dla „zwykłego zjadacza chleba”, co może wyrabiać w młodych poczucie źle rozumianej wyjątkowości, prowadzącej nie do działania na rzecz dobra wspólnego, ale do skrajnego indywidualizmu i egocentryzmu. Czy tak funkcjonujące instytucje oświatowo-wychowawcze kształtują społecznie dojrzałą osobowość?

Pojawiają się również głosy, iż szkoły te, nawet gdyby były ogólnodostępne i „wzorcowo prowadzone”, nie mają poważnego oddziaływania społecznego, ponieważ znajdują się w niszy społecznej - w porównaniu z placówkami prowadzonymi przez jednostki samorządu terytorialnego stanowią niewielki ich odsetek; wiele $\mathrm{z}$ nich nie jest także dotowana tak, jak szkoły samorządowe, stąd też boryka się z licznymi niedostatkami, co może niewłaściwie wpływać na proces wychowawczo-dydaktyczny.

Czy zatem współczesne polskie szkoły katolickie wychowują dzieci i młodzież do odpowiedzialności społecznej? Czy w pełni kształtują społecznie dojrzałą osobowość przyszłych pokoleń Polsków? Są to pytania otwarte, na które trudno jednoznacznie odpowiedzieć, stanowiące podstawę dalszych, pogłębionych badań empirycznych poszczególnych, konkretnych placówek.

\section{Contemporary Catholic School as a Place of Creating Socially Mature Personality of Children and Teenagers (Summary)}

This article deals with contemporary catholic school as one of the educational institutions creating socially mature personalities of children and teenagers. The author presents catholic school as a place of integral education, serving the nation, acting for the common good, creating patriotic conduct, a sense of the national status and being open to the other nations. The foundation of these activities is the fact that the whole educational system is based on educating children and young people for the values such as freedom, justice, responsibility, respect and brotherhood. Young people as future citizens, prepared for the social, political, economic and cultural life of the country and the world, can become the foundation for building sound and strong moral principles in society. The main element of the deliberations of this article is asking the question: Are the educational principles (in the statute, educational programmes, and plans) which are the basis of functioning of the catholic schools in Poland, really put into practice? Do these institutions really influence society by creating the mature personality of the young person? 
Key words: Catholic school; integral upbringing; bringing up to social values; the civil upbringing.

\section{Współczesna szkoła katolicka placówką kształtowania społecznie dojrzałej osobowości dzieci i młodzieży (Streszczenie)}

Artykuł rozpatruje współczesną szkołę katolicką jako jedną z instytucji oświatowych kształtujących społecznie dojrzałą osobowość dzieci i młodzieży. Autorka ukazuje placówkę katolicką jako miejsce, w którym z założenia podstawę jej działania stanowi integralne wychowanie, a zatem również jako środowisko kształtowania wśród młodych postawy służby społeczeństwu, działania na rzecz dobra wspólnego oraz formowania postaw patriotycznych, więzi i przynależności do własnego narodu, a także zdrowej „otwartości” wobec innych narodów. Fundamentem tych działań wydaje się być głównie oparcie systemu pedagogicznego tych placówek na wychowaniu dzieci i młodzieży ku wartościom, w tym także wartościom społecznym, wchodzącym w zakres wychowania obywatelskiego - między innymi wartościom wolności, sprawiedliwości, odpowiedzialności, szacunku, braterstwa. Młodzi jako przyszli obywatele, tak przygotowani do uczestnictwa w społecznym, politycznym, gospodarczym i kulturalnym życiu kraju i świata, mogą stać się podstawą budowania zdrowych i mocnych zasad moralnych w społeczeństwie. Przewodnim elementem rozważań jest nieustanne stawianie pytania: Czy udokumentowane założenia wychowawcze (w statutach, programach wychowawczych, planach pracy), stanowiące bazę funkcjonowania szkół katolickich w Polsce, są rzeczywiście wprowadzane w życie, a w konsekwencji, czy owe placówki pozytywnie oddziałują na rzeczywistość społeczną, kształtując społecznie dojrzałą osobowość młodego człowieka?

Słowa kluczowe: szkoła katolicka; wychowanie integralne; wychowa nie do wartości społecznych; wychowanie patriotyczne.

\section{Bibliografia}

Broda-Wysocki, Piotr. Rozwój społeczeństwa obywatelskiego w Polsce. Warszawa: IPiSS, 2003.

Chrobak, Stanisław. Koncepcja wychowania personalistycznego w nauczaniu Karola Wojtyty - Jana Pawła II. Warszawa: Wydawnictwo Salezjańskie, 1999.

Denek, Kazimierz. „Wartości i cele edukacji szkolnej”. Edukacja 3 (2000): 4-7. 
Encyklopedia pedagogiczna XXI wieku, t. 5, red. Tadeusz Pilch. Warszawa: Wydawnictwo Żak, 2006.

Furmanek, Waldemar. „Wychowanie do wartości drogą budowania tożsamości szko-

ły". W: Kreowanie tożsamości szkoty, t. 2: Konteksty historyczne, spoleczno-kulturowe, edukacyjne, red. Krystyna Chałas, Beata Komorowska, 183-194. Lublin: KUL, 2009.

http://wnk.kuria.zg.pl/szkoly_katolickie_w_polsce.html (27.09.2015).

http://www.rsk.edu.pl/index.php?option=com_content\&view=article\&id=93:szkoa -z-dusz\&catid=48:media-o-rsk\&Itemid=161 (27.09.2015).

Hurło, Lucyna. „Hierarchia wartości wśród młodzieży. Prawda czy złudzenie”. W: Pedagogika chrześcijańska. Tradycja, współczesność, nowe wyzwania, red. Jarosław Michalski, Aldona Zakrzewska, 438-447. Toruń: Wydawnictwo Adam Marszałek, 2010.

Kietlińska, Krystyna. Rola trzeciego sektora w społeczeństwie obywatelskim. Warszawa: Wydawnictwo Dyfin, 2010.

Klepacz, Michał. Duchowieństwo wobec nowoczesnych pradów w szkole polskiej. Kielce: Drukarnia św. Józefa, 1930.

Kunowski, Stefan. Podstawy wspótczesnej pedagogiki. Warszawa: Wydawnictwo Salezjańskie, 1996.

Maj, Adam. „Wartości religijne konstytuujące tożsamość szkoły katolickiej”. W:

Kreowanie tożsamości szkoty, t. 2: Konteksty historyczne, społeczno-kulturowe, edukacyjne, red. Krystyna Chałas, Beata Komorowska, 561-571. Lublin: KUL, 2009.

Maj, Adam. Szkolnictwo katolickie w III RP (1989-2001). Warszawa: Wydawnictwo Adam, 2002.

Mariański, Janusz. Kryzys moralny czy transformacja wartości? . Lublin: KUL, 2001.

Michałowski, Stanisław. Pedagogia wartości. Bielsko-Biała: Wydawnictwo Debit, 1993.

Olbrycht, Katarzyna. Prawda, dobro i piękno w wychowaniu czlowieka jako osoby. Katowice: UŚ, 2000.

Rada Szkół Katolickich. Informator adresowy szkót katolickich w Polsce. Warszawa: Rada Szkół Katolickich, 2011.

Rada szkół Katolickich. Informator adresowy szkół katolickich w Polsce. Warszawa: Rada Szkół Katolickich, 2014.

Rada Szkół Katolickich. Spotkanie nauczycieli szkót katolickich w Polsce z kard. Zenonem Grocholewskim - Prefektem Kongregacji Edukacji Katolickiej. Warszawa: Rada Szkół Katolickich, 2008.

Sławiński, Stanisław. „Uczeń szkoły katolickiej. Wychowanie do odpowiedzialności”. Ateneum Kapłańskie 3 (2007): 477-485. 
Stużyć wzrastaniu w prawdzie i miłości. Wybór dokumentów Kościoła na temat szkoty katolickiej $i$ wychowania, red. Janusz Poniewierski. Kraków: Wydawnictwo AA, 2009.

Sygut, Marek. „Szkoła katolicka - kontekst prawny”. Ignacjański Model Wychowania 1 (1995): 50-56.

Szkoła katolicka w nauczaniu Kościoła. Wybór dokumentów, red. Andrzej Dymer. Szczecin-Warszawa: Centrum Edukacyjne Archidiecezji Szczecińsko-Kamieńskiej, 2002.

Śliwińska, Teresa. „Potrzeba zakładania szkół katolickich”. Katecheta 3 (2003): 69-72.

Wojtyła, Karol. Miłość i odpowiedzialność. Lublin: KUL, 2001.

Wychowanie w nauczaniu Jana Pawła II (1978-1999), red. Stanisław Urbański. Warszawa: Wyższa Szkoła Zarządzania i Przedsiębiorczości im. Bogdana Jańskiego, 2000.

Wychowanie w nauczaniu Jana Pawła II, red. Adam Wieczorek. Warszawa: Wyższa Szkoła Zarządzania i Przedsiębiorczości im. Bogdana Jańskiego, 2000.

Zakrzewska, Aldona. „Pedagogia szkoły katolickiej alternatywą wychowania w dobie ponowoczesności”. W: Opieka $i$ wychowanie - tradycja i problemy wspótczesne, red. Danuta Apanel, 147-157. Kraków: Wydawnictwo Impuls, 2009.

Zakrzewska, Aldona. „Szkoła katolicka - jej (bez)sens istnienia w środowisku lokalnym”. W: Różne oblicza funkcjonowania szkoły, red. Lucyna Hurło, Małgorzata Przybysz-Zaremba, 189-199. Olsztyn: Wydawnictwo Prospekt, 2010. 
